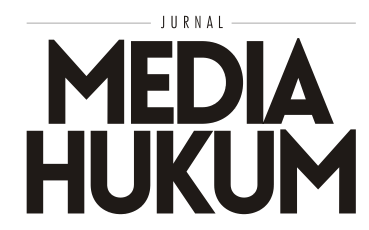

DOI: $10.18196 /$ jmh.2018.0096.1-8

Va.25 Na1/ JUN 2018

\title{
Tinjauan Hukum Islam Terhadap Fungsi Balai Harta Peninggalan dalam Mengurus Harta Kekayaan Orang yang Tidak Hadir
}

\author{
Prihati Yuniarlin, Endang H eriyani
}

DATA NASKAH

Masuk: 15 Januari 2018

Diterima: 27 April 2018

Terbit: 1 Juni 2018

KORESPONDEN PENULIS:

Fakultas Hukum, Universitas Muhammadiyah Yogyakarta. Jalan Brawijaya, Tamantirto, Kasihan, Bantul, Yogyakarta.

Email: eheriyani@gmail.com

\begin{abstract}
People who are absent do not lose their status as legal subjects who have rights and obligations. For this reason, it is necessary to protect both the interests and property. The purpose of this study was to find out whether the $\mathrm{H}$ eritage $\mathrm{H}$ all had fulfilled its function in managing the assets of people who were not present. This research is a normative legal research with a conceptual approach and a law approach. The informant in this study is an Islamic Civil Law Expert. The study showed 3 results. First, the $\mathrm{H}$ eritage Property has fulfilled its function in managing the assets of people who absent. Second, the existence of the Institution of Treasury $\mathrm{H}$ all can provide legal protection for the assets of people who absent. Third, the function of the Treasure $\mathrm{H}$ ouse in managing the assets of people who absent can be said to be in accordance with I slamic law. A lthough the task of managing or managing the assets of people who absent is different, in Islamic L aw the institution authorized to take care of the assets of people who absent is the Temporary Zakat A gency according to the Civil C ode, the management of assets that are not present is the $\mathrm{H}$ eritage $\mathrm{H}$ all . H owever, the essence is same, both the A mil Zakat Institution and BH P in principle represent the State in managing the assets of people who absent.
\end{abstract}

K eyword: Balai $\mathrm{H}$ arta Peninggalan, afwezig

\section{ABSTRAK}

O rang yang tidak hadir tidak kehilangan statusnya sebagai subyek hukum yang mempunyai hak dan kewajiban. U ntuk itu, perlu dilindungi baik kepentingan maupun harta bendanya. Tujuan penelitian ini adalah untuk mengetahui apakah Balai $\mathrm{H}$ arta Peninggalan telah memenuhi fungsinya dalam mengurus harta kekayaan orang yang tidak hadir, untuk mengetahui apakah adanya lembaga Balai $\mathrm{H}$ arta Peninggalan dapat memberikan perlindungan hukum terhadap harta kekayaan orang yang 
tidak hadir serta untuk mengetahui apakah fungsi Balai $\mathrm{H}$ arta Peninggalan dalam mengurus harta kekayaan orang yang tidak hadir sesuai dengan hukum Islam. Penelitian ini merupakan penelitian hukum normatif dengan pendekatan konseptual (conceptual approach) dan pendekatan undang-undang, yang mengkaji bahanbahan hukum dengan cara studi lapangan dan studi pustaka. N ara sumber dalam penelitian ini adalah Pakar Hukum Perdata Islam. Berdasarkan hasil penelitian diketahui bahwa: 1) Balai $\mathrm{H}$ arta Peninggalan telah memenuhi fungsinya dalam mengurus harta kekayaan orang yang tidak hadir. M eskipun harta kekayaan orang yang tidak hadir yang diurus oleh BH P Semarang tidak banyak tetapi BHP Semarang pernah melaksanakan fungsinya dalam mengurus harta kekayaan orang yang tidak hadir; 2) Keberadaan lembaga Balai $\mathrm{H}$ arta Peninggalan dapat memberikan perlindungan hukum terhadap harta kekayaan orang yang tidak hadir. $\mathrm{H}$ al ini dapat dilihat dari peran BHP sebagai lembaga yang berfungsi untuk mengurus harta kekayaan orang yang tidak hadir hadir sehingga harta kekayaan tersebut tidak menjadi sengketa di kemudian hari oleh orang-orang yang tidak bertanggungjawab; 3) Fungsi Balai $\mathrm{Harta}$ Peninggalan dalam mengurus harta kekayaan orangyang tidak hadir dapat dikatakan sesuai dengan hukum Islam. M eskipun yang bertugas mengelola atau mengurus harta kekayaan orang yang tidak hadir berbeda, dalam $\mathrm{H}$ ukum I slam lembaga yang berwenang mengurus harta kekayaan orang yang tidak hadir adalah Badan A mil Zakat sementara menurut Kitab U ndang-undang H ukum Perdata pengurusan harta kekayaan orang yang tidak hadir adalah Balai Harta Peninggalan. Namun demikian esensinya sama, baik Lembaga A mil Zakat maupun BHP pada prinsipnya mewakili N egara dalam mengurus harta kekayaan orang yang tidak hadir. K ata kunci: B H P, Pengurusan harta, orang yang tidak hadir (afwezig)

\section{PENDAHULUAN}

Pada masa sekarang semua manusia merupakan subjek hukum. M anusia merupakan subjek hukum selama manusia itu masih hidup, yaitu sejak saat dilahirkan sampai meninggal dunia (M arzuki: 2009:242). Demikian juga menurut Subekti, di mana saja setiap orang adalah subyek hukum atau pembawa hak (1996: 12). Subyek hukum atau persoon adalah siapa saja yang dapat menjadi pendukung hak-hak dan kewajiban-kewajiban hukum (Satrio, 1999: 13). Sebagai pendukung atau pembawa hak, manusia berhak untuk hidup, berhak atas nama baik, berhak untuk memiliki harta benda, dan sebagainya.

Manusia sebagai pendukung hak dan kewajiban dimulai sejak dilahirkan. Seorang bayi yang masih berada dalam kandungan ibunya dianggap dapat mempunyai kewenangan hukum bila ada kepentingan yang menghendaki dan nantinya dilahirkan dalam keadaan hidup. Hal ini merupakan perkecualian yang ditentukan dalam Pasal 2 KUHPerdata yang menyatakan "Anak yang ada dalam kandungan seorang perempuan dianggap sebagai telah dilahirkan bila mana juga kepentingan si anak menghendakinya. Mati sewaktu dilahirkan, dianggaplah ia tak pernah telah ada". Ketentuan yang termuat dalam Pasal 2 KUHPerdata tersebut sering disebut rechtsfictie, karena hukum membuat fictie seakanakan anak dalam kandungan sudah dilahirkan (Syahrani, 1992: 45, dan (Satrio,1992:27).

Berakhirnya seseorang sebagai pendukung hak dan kewajiban apabila ia meninggal dunia. Artinya selama seseorang masih hidup selama itu pula ia mempunyai kewenangan berhak. Pasal 3 KUHPerdata menentukan “Tiada suatu hukumanpun mengakibatkan kematian perdata, atau kehilangan segala hak perdata". Dalam bahasa Belanda orang yang tidak hadir disebut afwezig. Orang yang tidak hadir (afwezig) adalah orang yang meninggalkan tempat tinggalnya tanpa menunjuk orang lain untuk mewakili dan mengurus kepentingannya (Satrio, 1999: 208).

Orang yang meninggalkan tempat tinggalnya dan tidak diketahui keadaannya dengan pasti apakah masih hidup atau telah meninggal dunia dalam hukum Islam dikenal dengan istilah mafqud (Hasan,2004: 64). Dengan demikian keadaan afwezig maupun mafqud tidak menghilangkan kedudukan manusia sebagai subyek hukum, yaitu sebagai penyandang hak dan kewajiban. Hal tersebut berarti tetap wenang berhak dan wenang berbuat atau cakap bertindak atas harta bendanya.

Pada umumnya setiap orang yang telah cakap melakukan perbuatan hukum dapat mengurus sendiri kepentingan dan harta bendanya. Demikian juga dapat melaksanakan kewajiban-kewajibannya. Orang yang tidak hadir selama 
masih hidup, dimanapun ia berada selain mempunyai hak juga tetap dibebani kewajiban-kewajiban, dan cakap melakukan perbuatan hukum terhadap harta bendanya. Orang yang tidak hadir, tidak dapat mengurus sendiri kepentingan maupun harta benda yang berada di tempat tinggalnya.

Kewajiban orang yang afwezig atau mafqud tidak berbeda dengan orang yang hadir/berada di tempat, misalnya; bila statusnya sebagai seorang suami maka wajib memberikan nafkah kepada isteri dan anak-anaknya. Demikian juga bila berkedudukan sebagai seorang yang meminjam uang, maka tetap berkewajiban melakukan pembayaran kepada krediturnya. Kewajiban-kewajiban orang yang afwezig tersebut dapat dibayar atau dipenuhi dengan harta benda yang dimilikinya.

Dalam kehidupan masyarakat, seseorang dapat meninggalkan tempat tinggalnya tanpa memberikan surat kuasa kepada orang lain untuk mewakili dirinya dalam mengurus harta benda dan segala kepentingannya, karena berbagai alasan. Berdasarkan hasil penelitian (Heriyani dan Yuniarlin, 2009) dapat diketahui bahwa adanya orang afwezig atau meninggalkan tempat tinggalnya, dikarenakan sebelumnya menderita gangguan jiwa. Akibatnya orang tersebut tanpa disadari meninggalkan tempat tinggalnya. Keadaan tersebut berlangsung cukup lama, tanpa ada beritanya dan akhirnya tidak kembali ketempat tinggalnya. Selain itu juga dapat disebabkan karena pergi bekerja ke luar daerah pada jaman penjajahan sebelum kemerdekaan. Keadaan tersebut berlangsung cukup lama, tanpa ada beritanya dan akhirnya tidak kembali ke tempat tinggalnya, sehingga tidak diketahui dimana keberadaan/domisilinya. Selain itu penyebab seseorang meninggalkan tempat tinggalnya karena merantau mencari pekerjaan di daerah di luar tempat tinggalnya dalam waktu yang lama dan juga tidak memberi kabar kepada sanak keluarganya.

Adanya orang yang afwezig atau mafqud dapat menimbulkan permasalahan bagi keluarga yang ditinggalkan, pihak ketiga, maupun kreditur ataupun debiturnya. M isalnya; orang yang afwezig atau mafqud berstatus sebagai seorang suami, maka kedudukannya sebagai kepala keluarga mempunyai kewajiban yang harus ditunaikan kepada isteri dan anak-anaknya. Dalam keadaan afwezig atau mafqud maka seorang suami tidak dapat memenuhi hak-hak isteri dan anaknya. Kreditur dari orang yang afwezig atau mafqud akan merasa dirugikan karena tidak dipenuhi hak-haknya. Orang yang afwezig atau mafqud jika mempunyai debiturpun juga akan dapat menimbulkan kesulitan, jika debitur ingin melunasi kewajibannya supaya berakhir perikatannya. Persoalan yang berkaitan dengan hal ini misalnya; kepada siapa debitur harus melakukan pembayaran.

Dari ketentuan Pasal 463-465 KUHPerdata, dapat diketahui adanya kewajiban Balai Harta Peninggalan (BHP) yang berkaitan dengan orang yang afwezig adalah:

1) Pengadilan Negeri tempat tinggal orang yang tidak ada di tempat dapat menunjuk Balai Harta Peninggalan supaya mengurus seluruh atau sebagian harta kekayaan dan kepentingannya, juga supaya membela hak-hak si afwezig dan mewakili dirinya.

Pengadilan Negeri berwenang pula memerintahkan pengurusan harta kekayaan dan perwakilan kepentingan kepada seorang atau lebih dari keluarga sedarah atau semenda si tak hadir yang ditunjuk oleh pengadilan atau kepada isteri atau suaminya dengan kewajiban satusatunya apabila si afwezig pulang kembali, maka keluarga, isteri atau suami tadi harus mengembalikan kepadanya harta kekayaan itu dan harganya, setelah dikurangi dengan segala hutang si afwezig yang telah dilunasinya dan tanpa hasil-hasil atau pendapatannya.

2) Balai Harta Peninggalan setelah mengadakan penyegelan wajib membuat daftar lengkap dari segala harta kekayaan yang dipercayakan kepadanya.

3) Balai Harta Peninggalan setiap tahun wajib secara singkat memberikan perhitungan tanggung jawab kepada jawatan kejaksaan pada Pengadilan Negeri yang mengangkatnya dan memperlihatkan pada jawatan tersebut segala efek-efek dan surat-surat berkenaan dengan pengurusannya.

Dengan demikian BHP wajib untuk mengurus harta benda maupun kepentingan, serta membela hak-hak orang yang afwezig. Seharusnya orang yang afwezig apabila pulang kembali ketempat tinggalnya, dapat memperoleh kembali harta bendanya, karena pihak-pihak yang menguasai harta bendanya ketika si afwezig meninggalkan tempat tinggalnya, mempunyai kewajiban mengembalikan harta bendanya. 
Berdasarkan Pasal 1 ayat (1) Keputusan M enteri Kehakiman RI Nomor M.01.PR.07.01-80 Tahun 1980 tentang Organisasi dan Tata Kerja Balai Harta Peninggalan menentukan bahwa Balai Harta Peninggalan adalah unit pelaksana penyelenggara hukum di bidang harta peninggalan dan perwalian dalam lingkungan Departemen Kehakiman, yang berada di bawah dan bertanggungjawab langsung kepada Direktur Jenderal Hukum dan Peraturan Perundangundangan melalui Direktur Perdata, mengurus harta kekayaan dan kepentingan orang yang dinyatakan tidak hadir (afwezig).

M enurut Pasal 61 Instruksi Untuk Balai Harta Peninggalan di Indonesia, Balai Harta Peninggalan wajib mengurus harta kekayaan dan kepentingan orang yang dinyatakan tidak hadir (afwezig). Pada masa lalu maupun masa sekarang adanya orang yang afwezig atau mafqud selalu dapat ditemui. Pada masa mendatangpun adanya orang yang afwezig atau mafqud akan dapat ditemui. Hal ini karena adanya kenyataan orang yang hilang, adanya bencana alam atau musibah seperti pesawat terbang jatuh yang tidak dapat ditemukan, adanya kapal yang karam dan lain-lain.

Pada saat sekarang eksistensi Balai Harta Peninggalan belum banyak dikenal masyarakat. Banyak masyarakat yang tidak tahu bahwa lembaga BHP masih ada dan mempunyai tugas pokok dan fungsi memberikan pelayanan hukum bagi masyarakat. (Heriyani; 2015: 218). Demikian juga fungsi BHP untuk mengurus kepentingan dan harta orang yang afwezig. Untuk itu perlu ada upaya-upaya agar BHP dapat memenuhi fungsinya sebagai pengurus kepentingan dan harta orang yang afwezig.

\section{RUMUSAN MASALAH}

1. Apakah Balai Harta Peninggalan telah memenuhi fungsinya dalam mengurus harta kekayaan orang yang tidak "hadir"/afwezig?

2. A pakah adanya lembaga Balai Harta Peninggalan dapat memberikan perlindungan hukum terhadap harta kekayaan orang yang tidak "hadir"/afwezig?

3. Apakah fungsi Balai Harta Peninggalan dalam mengurus harta kekayaan orang yang tidak "hadir"/afwezig sesuai dengan hukum Islam?

\section{METODE PENELITIAN}

Penelitian ini merupakan penelitian hukum normatif dengan mencari asas-asas, doktrin-doktrin dan sumber hukum dalam arti filosofis, sosiologis dan yuridis (Soekanto, 1984: 5), untuk menemukan kesesuaian antara prinsipprinsip yang berlaku dalam pengurusan harta kekayaan menurut hukum Islam dengan pengurusan harta kekayaan orang yang tidak hadir yang dilaksanakan oleh Balai Harta Peninggalan.

Bahan penelitian berupa bahan hukum primer, bahan hukum sekunder, bahan hukum tersier. Bahan hukum primer, merupakan bahan pustaka yang berisikan peraturan perundang-undangan yang terkait dengan obyek penelitian, yaitu KUHPerdata, Keputusan Menteri Kehakiman RI Nomor M.01.PR.07.01-80 Tahun 1980 tanggal 19 Juni 1980 tentang Organisasi dan Tata Kerja Balai Harta Peninggalan. Bahan hukum sekunder, yaitu bahan-bahan yang erat kaitannya dengan bahan hukum primer, dan dapat membantu untuk proses analisis, misalnya: buku-buku ilmiah, hasil penelitian, jurnal, makalah-makalah, dan pendapat pakar (nara sumber) yang berkaitan dengan obyek penelitian. Bahan hukum tersier, yaitu: kamus bahasa arab, kamus istilah hukum, Black's Law Dictionary, dan kamus Inggris-Indonesia. Narasumber dalam penelitian ini adalah Pakar Hukum Islam yaitu Drs. Muhsin Hariyanto, M.Ag., dan Dr. H.M. Khaeruddin Hamsin, LC.M A. Data yang diperoleh dari studi pustaka disusun secara sistematis dan dianalisis

Secara preskriptif (Harkrisnowo, 2004: 16) dengan pendekatan kualititatif (Strauss, 2003: 35), yaitu dengan memberikan pemaparan dan menjelaskan secara holistik dan mendalam (verstehen), (M oleong, 1996: 43) untuk mengungkap kesesuaian antara fungsi Balai Harta Peninggalan dalam mengurus harta orang yang tidak hadir dengan Hukum Islam.

\section{HASIL PENELITIAN DAN ANALISIS}

\section{A. Penyebab Adanya 0 rang yang Tidak Hadir/ Afwezig.}

Berdasarkan hasil penelitian dapat diketahui bahwa or- 
ang dalam keadaan afwezig atau meninggalkan tempat tinggalnya dengan tidak memberi kuasa kepada seorang wakil guna mewakili dirinya dan mengurus harta kekayaannya, maupun kepentingannya, dikarenakan sebelumnya menderita gangguan jiwa. Akibatnya orang tersebut tanpa disadari meninggalkan tempat tinggalnya. Keadaan tersebut berlangsung cukup lama, tanpa ada beritanya dan akhirnya tidak kembali ke tempat tinggalnya. Selain itu, juga dapat disebabkan karena pergi bekerja ke luar daerah pada jaman penjajahan sebelum kemerdekaan. Keadaan tersebut berlangsung cukup lama, tanpa ada beritanya dan akhirnya tidak kembali ke tempat tinggalnya, sehingga tidak diketahui dimana keberadaan/domisilinya (Heriyani dan Yuniarlin, 2009).

\section{B. Prosedur Pengajuan Permohonan afwezig di Pengadilan Negeri.}

Seseorang yang meninggalkan tempat tinggalnya tanpa memberikan surat kuasa kepada orang lain untuk mengurus harta benda maupun kepentingannya dapat menimbulkan ketidakpastian hukum. Apalagi bila kepergiannya tersebut dalam jangka waktu yang lama dan tanpa memberikan kabar mengenai keadaannya maupun keberadaannya, dapat menghambat urusan dari pihak-pihak yang berkepentingan. Pihak-pihak yang berkepentingan seperti keluarga sedarahnya, isteri/suaminya, atau krediturnya untuk dapat mendapatkan kepastian hukum mengenai status orang yang meninggalkan tempat tinggalnya tersebut, dapat mengajukan permohonan kepada hakim Pengadilan Negeri agar ditetapkan sebagai orang yang afwezig yang meninggal dunia secara hukum.

Menurut hasil penelitian di Pengadilan Negeri, prosedur pengajuan permohonan afwezig adalah (Heriyani dan Yuniarlin, 2009):

1. Pemohon mengajukan permohonan penetapan afwezig bagi orang yang meninggalkan tempat tinggal, yang ditujukan kepada Ketua Pengadilan Negeri. Permohonan ini diterima oleh Kepaniteraan Perdata Pengadilan Negeri

2. Membayar biaya panjar perkara melalui Bank ke rekening Pengadilan (rekening uang pihak ketiga). Selain itu pemohon juga harus membayar biaya pengumuman di surat kabar sebagai salah satu syarat pengajuan penetapan afwezig. Adapun yang menentukan dan menyelenggarakan pengumuman di surat kabar adalah pihak Pengadilan Negeri

3. Kepaniteraan Perdata mendaftar permohonan pemohon dalam register perkara dan menentukan nomor perkara

4. Ketua Pengadilan Negeri menentukan hakim yang menyidangkan perkara

5. Hakim menentukan hari sidang

6. Jurusita melakukan pemanggilan terhadap para pihak untuk menghadiri sidang

7. Pelaksanaan persidangan. Persidangan dimulai dengan beberapa tahapan yaitu:

a) Hakim memerintahkan untuk memanggil orang yang tidak ditempat (afwezig) melalui radio atau media massa

b) Panggilan dilakukan sebanyak tiga kali, panggilan pertama ketika pertama kali sidang, selanjutnya panggilan diperintahkan dalam materi sidang, panggilan bisa dilakukan melalui radio atau media massa, atau keduanya. Jika pemanggilan melalui radio, panggilan dilakukan sebanyak 4 kali dalam satu bulan atau setiap minggu, demikian seterusnya pemanggilan dilakukan selama tiga bulan berturutturut. Tetapi jika pemanggilan dilakukan melalui media massa, pemanggilan dilakukan sebulan sekali berturutturut selama tiga bulan

c) Hakim tetap memerintahkan termohon tetap hadir pada persidangan berikutnya, walaupun kenyataannya termohon tidak hadir karena tidak ada di tempat

d) Pada pemanggilan ketiga, apabila termohon tidak hadir, maka persidangan dilanjutkan dengan acara verstek

e) Persidangan dilanjutkan secara terbuka

f) Dilanjutkan pembacaan permohonan, dalam persidangan kali ini pemohon diberi kesempatan untuk merubah, menambah, atau mengurangi isi permohonan, jika ada perubahan pada isi permohonan, maka perubahan tersebut langsung disampaikan dalam persidangan dan hakim akan menuliskan dalam permohonan dengan cara memberi 'catatan sah diganti' atau 'sah ditambah', atau 'sah 
dicoret', kemudian diparaf oleh pemohon dan hakim

g) Hakim memerintahkan pada pemohon untuk membuktikan dalil permohonannya

h) Pembuktian harus didasarkan pada alat-alat bukti yang sah

i) Penetapan permohonan oleh hakim.

\section{Pengurusan $\mathrm{H}$ arta K ekayaan orang yang} tidak hadir oleh BH P dan Pengurusan Harta Kekayaan orang yang tidak hadir menurut

\section{H ukum Islam.}

Pengurusan Harta Kekayaan orang yang tidak hadir, jika orang yang tidak hadir ini mempunyai keluarga yang berkedudukan sebagai ahli waris, seperti orang tua, saudara kandung, maka pengurusannya akan diserahkan kepada ahli warisnya. Namun jika orang yang tidak hadir tidak mempunyai keluarga maka disini Balai Harta Peninggalan mempunyai tugas untuk mengurusnya sebagaimana diatur dalam Pasal 463 KUH Perdata jo. Pasal 61 Instruksi Untuk BHP di Indonesia.

Pelaksanaan tugas Balai Harta Peninggalan untuk mengurus harta orang yang tidak hadir (afwezig) dimulai dengan kegiatan menyampaikan hasil penetapan/putusan tentang afwezig dari pengadilan kepada Ketua Balai Harta Peninggalan (BHP). Setelah penetapan/putusan tentang afwezig diserahkan, kegiatan selanjutnya adalah mendisposisikan permohonan kepada Sekretaris BHP, setelah permohonan didistribusikan kepada sekretaris berkas pemohon diserahkan kepada ATH (Anggota Teknis Hukum) untuk ditindaklanjuti. ATH akan Memeriksa berkas, jika berkas lengkap maka ATH akan memberi paraf untuk ditindaklanjuti. Jika berkas tidak lengkap, berkas akan dikembalikan kepada pemohon untuk dilengkapi. Selanjutnya BHP akan membuat pengumuman penetapan/putusan pengadilan tentang afwezig pada Koran Nasional dan Koran Lokal serta dimuat dalam Berita Negara RI.

Kegiatan selanjutnya adalah melakukan pemanggilan kepada pemohon dan membuat Berita Acara (BA) pencatatan harta. Balai Harta Peninggalan kemudian akan memberitahukan secara tertulis kepada BPK, Kejaksaan Negeri, BPN (Badan Pertanahan Nasional) dan meminta keterangan kepada pengadilan ada tidaknya perlawanan terhadap Penetapan/putusan tentang afwezig. Jika pihak ketiga berkeinginan membeli harta orang yang afwezig maka orang tersebut harusmengajukan permohonan membeli boedel afwezig kepada Ketua BHP. Dalam melaksanakan fungsi Balai Harta Peninggalan dalam mengurus harta kekayaan orang yang tidak hadir, BHP akan mengajukan permohonan ijin menjual kepada Menteri Hukum dan HAM RI Cq. Dirjen AHU tembusan disampaikan kepada Direktur Perdata dan Kepala Kantor wilayah setempat, setelah Tim gabungan melaksanakan verifikasi lapangan. Usulan permohonan ijin menjual akan diperiksa, jika setuju ditandatangani dan disampaikan kepada Dirjen AHU untuk ditindaklanjuti, jika tidak setuju dikembalikan kepada Dirjen AHU untuk dilengkapi.

Ketua Balai Harta Peninggalan akan menerima persetujuan ijin menjual dan tembusannya disampaikan kepada Direktur Perdata. Setelah persetujuan ijin menjual dari Menteri Hukum dan HAM RI Cq. Dirjen AHU diterima BHP akan pengajuan permohonan penetapan ijin menjual boedel afwezig kepada Pengadilan dilengkapi usul penunjukan Appraisal/Tim penaksir harga tembusan, disampaikan kepada Direktur Perdata dan Kepala Kantor wilayah setempat. Selanjutnya BHP melaksanakan jual beli boedel afwezig dengan pemohon dihadapan Notaris/PPAT. Dalam hal ini Balai Harta Peninggalan mewakili orang yang afwezig menerima salinan resmi akta jual beli.

Terkait dengan pelaksanaan fungsi Balai Harta Peninggalan dalam mengurus harta kekayaan orang yang tidak hadir, Balai Harta Pening galan Semarang pernah menangani kasus harta kekayaan orang yang tidak hadir. Kasus ini terkait dengan tanah beserta bangunan di atasnya, yang ditempati sebuah kantor. Setelah beberapa puluh tahun kantor tersebut berencana membeli tanah dan bangunan tersebut, namum ternyata pemiliknya tidak diketahui lagi, maka setelah ada putusan hakim pemilik dalam keadaan afwezig (tidak hadir), Balai Harta Peninggalan mempunyai tugas untuk mewakili pemilik berkedudukan sebagai penjual.

Balai Harta Peninggalan bertindak sebagai penjual karena penjualnya (dalam hal ini pemilik barang ditetapkan sebagai orang yang tidak hadir (afwezig). Hasil penjualan tanah beserta bangunan diserahkan ke kas negara sebagai penda- 
patan bukan pajak. Menurut hukum Islam, orang yang meninggalkan tempat tinggalnya dan tidak diketahui keadaannya dengan pasti apakah masih hidup atau telah meninggal dunia dikenal dengan istilah mafqud (Hasan, 2004:64). Keadaan mafqud seseorang harus dibuktikan dengan adanya penetapan dari hakim Pengadilan Agama (Heriyani, 2008: 117). M enurut hukum waris Islam, jika seorang meninggal dunia tidak mempunyai ahli waris maka hartanya diserahkan kepada baitul mal yang dipergunakan untuk kemaslahatan umat Islam secaara umum. Ini adalah pendapat madzhab Syafii dan Maliki yang merupakan pendapat sebagian sahabat Nabi M uhammad SAW seperti Zaid bin Tsabit dan Abdullah bin Abbas (Shabuni dalam Adila, 2013: 23).

Baitul M al berasal dari bahasa Arab bait yang berarti "rumah", dan al-mal yang berarti "harta". Baitul M al berarti rumah untuk mengumpulkan atau menyimpan harta. Baitul Mal adalah suatu lembaga atau pihak (al jihat) yang mempunyai tugas khusus menangani segala harta umat, baik berupa pendapatan maupun pengeluaran negara. (https://id.wikipedia.org/wiki/Baitul_Mal). Dalam hukum waris Islam apabila pada saat warisan terbuka ahli waris tidak ada, maka warisan akan beralih kepada lembaga baitul mal (M oechthar, 2017: 297).

Menurut Pasal 191 Kompilasi Hukum Islam bila pewaris tidak meninggalkan ahli waris sama sekali atau ahli warisnya tidak diketahui ada atau tidaknya, maka harta tersebut atas putusan pengadilan agama diserahkan penguasaannya kepada Baitul M al untuk kepentingan Agama Islam dan kesejahteraan umum. Baitul Mal adalah Balai Harta Keagamaan (Pasal 171 huruf i Kompilasi Hukum Islam). Terkait dengan pengurusan harta kekayaan orang yang tidak hadir (mafqud) menurut nara sumber yang merupakan pakar Hukum Islam bahwa di dalam hadist tidak secara eksplisit mengaturnya, namun dalam fiqih ijtihad ulama, dapat diketahui bagaimana ulama mempertimbangkan untuk kemaslahatan umat, harta yang ditinggalkan oleh mafqud dikembalikan kepada negara untuk kemaslahatan umat. Jadi harta yang ditinggalkan oleh orang yang tidak hadir (mafqud) dikembalikan pada negara melalui Badan Amil Zakat untuk disalurkan kembali kepada masyarakat yang membutuhkan.

Di Indonesia lembaga yang berhak mengurus harta warisan dalam hal ahli waris tidak ada, yaitu BHP (Balai Harta Peninggalan), Badan Amil Zakat serta Baitul Mal Aceh khusus untuk orang Aceh. BHP berhak mengelola harta warga negara Indonesia yang beragama selain Islam, Badan Amil Zakat mengelola harta warga negara Indonesia yang beragama Islam, khusus di Aceh Warga Negara Indonesia yang beragama Islam dikelola Baitul Mal Aceh (Adila, 2013: 93). Pada saat sekarang semua penduduk di Indonesia dapat memanfaatkan lembaga BHP, jadi BHP tidak hanya berhak mengelola harta warga negara Indonesia yang beragama selain Islam.

Badan Amil Zakat dibentuk pemerintah Indonesia menjalankan fungsi Baitul M al (berdasarkan Undang-Undang No. 38 Tahun 1999 tentang Pengelolaan Zakat). Pada tahun 2011 disahkan Undang-undang No. 23 Tahun 2011 Badan Amil Zakat menjadi Baznas (Badan Amil Zakat Nasional). M enurut hasil penelitian Ika Lestari, upaya hukum yang dapat dilakukan ahli waris terhadap harta kekayaan mafqud adalah ahli waris dapat mengajukan permohonan penetapan ke Peradilan Agama untuk mendapatkan penetapan ahli waris. Selanjutnya apabila seorang mafqud meninggalkan harta kekayaan tetapi tidak diketahui pemilik dan ahli warisnya, maka harta tersebut dikelola oleh Badan Amil Zakat Nasional, khusus untuk Aceh dikelola oleh Baitul M al (Lestari, 2016: 12).

\section{KESIMPULAN}

Berdasarkan hasil analisis dapat diambil kesimpulan bahwa:

1. Balai Harta Peninggalan telah memenuhi fungsinya dalam mengurus harta kekayaan orang yang tidak hadir. M eskipun harta kekayaan orang yang tidak hadir yang diurus oleh BHP Semarang tidak banyak tetapi BHP Semarang pernah melaksanakan fungsinya dalam mengurus harta kekayaan orang yang tidak hadir.

2. Keberadaan lembaga Balai Harta Peninggalan dapat memberikan perlindungan hukum terhadap harta kekayaan orang yang tidak hadir. Hal ini dapat dilihat dari peran BHP sebagai lembaga yang berfungsi untuk mengurus harta kekayaan orang yang tidak hadir hadir sehingga harta kekayaan tersebut tidak menjadi sengketa di kemudian hari oleh orang-orang yang tidak 
bertanggungjawab.

3. Fungsi Balai Harta Peninggalan dalam mengurus harta kekayaan orang yang tidak hadir dapat dikatakan sesuai dengan hukum Islam. Meskipun yang bertugas mengelola atau mengurus harta kekayaan orang yang tidak hadir berbeda, dalam Hukum Islam lembaga yang berwenang mengurus harta kekayaan orang yang tidak hadir adalah Badan Amil Zakat, sementara menurut Kitab Undang-undang Hukum Perdata pengurusan harta kekayaan orang yang tidak hadir adalah Balai Harta Peninggalan. Namun demikian esensinya sama, baik Badan Amil Zakat maupun BHP pada prinsipnya mewakili Negara dalam mengurus harta kekayaan orang yang tidak hadir.

\section{DAFTAR PUSTAKA}

\section{Buku-buku}

A ndreae, Fockema, 1983, Kamus Istilah H ukum Fockema Andreae Belanda- Indonesia, (diterjemahkan oleh Saleh Adiwinata dkk), Bina Cipta.

A sh-Shiddieqy, H asbi, 1984, Pengantar Fiqh Muamalah, Jakarta, Bulan Bintang.

A nwar, Syamsul , 2007, H ukum Perjanjian Syariah Studi tentang Teori Akad dalam Fikih Muamalat, Jakarta, PT Raja G rafindo Persada.

Almath, M uhammad, Faiz, 1991, 1100 Hadits Terpilih Sinar Ajaran M uhammad, Jakarta, Gema Insani.

Basyir, A hmad, Azhar 2000, A sas-asas H ukum M uamalat (H ukum Perdata Islam), Yogyakarta, U II Press.

H amid, Zahri, 1975, Pokok-pokok Hukum Kehartaan D alam Fiqih Islam, Yogyakarta, Lembaga Penerbitan IImiyah IAIN Sunan Kalijaga.

$\mathrm{H}$ asan, H asniah, 2004, Hukum Waris dalam Islam, Surabaya, G itamedia Pres.

M uhammad, A bdulkadir, 1990, H ukum Perdata Indonesia, Bandung, PT. Citra Aditya Bakti.

Moleong, Lexy J, 1996, M etodologi Penelitian Kualitatif, Bandung, Rosdakarya

M ardani, D r., 2011, Hukum Perkawinan Islam di Dunia Islam Modern, Yogyakarta, G raha IImu.

Mughniyah, M uhammad, Jadwal, 2006, Fikih Lima M azhab, Jakarta, Lentera.

M arzuki, Peter M ahmud , 2005, penelitian H ukum , Jakarta, Kencana. , 2009, Pengantar IImu H ukum, Jakarta, Kencana.
Prawirohamidjodjo, Soetojo, dan M arthalena Pohan, 1995, Hukum Orang dan Keluarga, Surabaya, Airlangga U niversity Press.

Sofwan, Sri Soedewi, M asjchoen 1964, Hukum Badan Pribadi, Yogyakarta, Yayasan Badan Penerbit Gadjah Mada.

Strauss, Anslem, 2003, Dasar-dasar Penelitian Kualitatif, terjemahan M uhammad Shodiq,

Yogyakarta, Pustaka Pelajar.

Syahrani , Riduan., 1992, Seluk beluk dan Asasasas H ukum Perdata, Bandung.Alumni.

Sabiq, Sayyid, 2006, Fiqih Sunnah Jilid 4, Jakarta, Pena Pundi Aksara.

Satrio J,1999, H ukum Pribadi Bagian I Persoon Alamiah, Bandung, PT. Citra Aditya Bakti.

Simanjuntak, P.N.H, 1999, Pokok-pokok Hukum Perdata Indonesia, Jakarta, D jambatan.

Soekanto, Soerjono, \& Sri Mamudji, 1985, Penelitian H ukum N ormatif, Jakarta, Raja G rafindo.

Sudarsono, 2001, Pokok-pokok H ukum Islam, Jakarta, PT Rineka Cipta.

Subekti, 1996, Perbandingan H ukum Perdata, Jakarta, PT Pradnya Paramita.

Sjarif , Surini A hlan dan Nurul Elmiyah, 2005, Hukum Kewarisan Perdata Barat Pewarisan M enurut Undangundang, Jakarta, Kencana dan Badan Penerbit Fakultas H ukum U niversitas Indonesia.

U sman, Rachmadi, 2006, A spek-aspek H ukum Perorangan dan Kekeluargaan di Indonesia, Jakarta, Sinar G rafika.

\section{Jurnal}

Heriyani, Endang, 2008, Perlindungan Hukum bagi $\mathrm{M}$ afqud dalam Pembagian $\mathrm{H}$ artaW arisan di Kabupaten Bantul, Jurnal M edia Hukum, Vol. 15, No. 1.

Heriyani, Endang, 2015, Fungsi BH P sebagai Wali Pengawas Terhadap Anak di Bawah Perwalian dalam Rangka Perlindungan Anak, Jurnal M edia H ukum, Vol. 22, N 0.2.

Lestari, Ika, 2016, Analisis YuridisTentang Tanggungjawab Pengurusan $\mathrm{H}$ arta $\mathrm{O}$ rang $\mathrm{H}$ ilang $\mathrm{M}$ enurut $\mathrm{H}$ ukum Islam (Studi Penetapan Nomor 137/ PDT.P/ 2013/ M SBNA), Jurnal Premise Law Jurnal, Vol. 3.

M oechtar, O emar, 2017, Kedudukan N egara Sebagai Pengelola Warisan A tas $\mathrm{H}$ arta Peninggalan Tak Terurus M enurut Sistem Waris Burgerlijk Wetboek, Jurnal Yuridika: Volume 32 No. 2.

Internet 
W ikipedia bahasa Indonesia, ensiklopedia bebas, Baitul M al, https:/ / id.wikipedia.org/ wiki/ Baitul_Mal, diakses taggal 15 Juli pukul 11.45 W IB).

\section{Skripsi}

Adila, Rasikh, 2013, Lembaga Pengelola H arta Waris di Indonesia dalam Kasus A hli W aris Tidak Ada, Skripsi, UIN Malang.

\section{Daftar Peraturan Perundang-undangan}

Kitab U ndang-U ndang H ukum Perdata

Peraturan Menteri Hukum dan Hak Asasi Manusia RI Nomor: M .01.H T.05.10 Tahun 1990;

Peraturan Menteri Hukum dan $\mathrm{H}$ ak Asasi Manusia RI Nomor: M .02-H T.05.10Tahun 2005.

Keputusan M enteri Kehakiman RI N omor M .01.PR.07.0180 tahun 1980 tanggal 19 Juni 1980 tentang O rganisasi dan TataKerja Balai Harta Peninggalan 